\title{
Eight years of clinical experience with digit replantation: Demographic characteristics and outcomes
}

\author{
Melike Oruç, M.D., ${ }^{1}$ Koray Gürsoy, M.D., ${ }^{1}$ Kadri Özer, M.D., ${ }^{2}$ Özlem Çolak, M.D., ${ }^{3}$ Yüksel Kankaya, M.D., ${ }^{1}$ \\ Nezih Sungur, M.D., ${ }^{1}$ Gürhan Mustafa Ulusoy, M.D., ${ }^{4}$ Uğur Koçer, M.D. ${ }^{1}$
}

\begin{abstract}
${ }^{1}$ Department of Plastic, Reconstructive and Aesthetic Surgery, Ankara Training and Research Hospital, Ankara-Turkey 2Department of Plastic, Reconstructive and Aesthetic Surgery, Aydın State Hospital, Aydın-Turkey

${ }^{3}$ Department of Plastic, Reconstructive and Aesthetic Surgery, Okmeydanı Training and Research Hospital, İstanbul-Turkey

${ }^{4}$ Private Practice, Ankara-Turkey
\end{abstract}

\begin{abstract}
BACKGROUND: Despite surgical and technical advances in microsurgery, it is still difficult to obtain satisfactory results after replantation of finger amputation. The aim of the present study was to discuss some of the many factors that can affect the success rate of replantation.
\end{abstract}

METHODS: A retrospective analysis of 60 patients with 85 finger replantations was performed. Revascularizations and replantations proximal to the metacarpophalangeal joint were excluded. Demographic characteristics of the patients, place of injury, mechanism of injury, level of amputation, and success rate were examined.

RESULTS: A total of 53 male and 7 female patients with mean age of 31 years were included in the study. Index finger (27\%) was the most commonly replanted digit. Left side was the more affected, with $62 \%$. Mechanism of injury was crush in $56 \%$, guillotine in $23 \%$, and avulsion in $21 \%$ of replanted digits. Success rate was $81 \%, 53 \%$, and $36 \%$ in guillotine, crush, and avulsion injuries, respectively.

CONCLUSION: In conclusion, the injury type and personal variables are very important in the rate of replantation success. Knowledge about the effects of different factors on the results of replantation surgery will provide guidance to hand surgeons in order to inform patients and their relatives properly.

Keywords: Amputation; finger; microsurgery; replantation.

\section{INTRODUCTION}

Although finger amputation does not threaten life, it can cause serious functional and psychological problems. Tamai and Komatsu performed the first successful replantation in 1965, and the operation is now widely performed throughout the world. ${ }^{[1]}$ In the literature, there are many reports about the success rate of replantation. Success can be affected by many factors, such as the level of injury, experience of the surgeon, mechanism of injury, age, gender, smoking addiction,

Address for correspondence: Melike Oruç, M.D.

Ankara Eğitim ve Araştırma Hastanesi, Plastik, Rekonstrüktif ve Estetik Cerrahi Kliniği, Ulucanlar, 06340 Ankara, Turkey

Tel: +90 312 - 595365 I E-mail: droruc@yahoo.com

Submitted: 03.06 .2016

Ulus Travma Acil Cerrahi Derg

Accepted: 08.11.2016

2017;23(4):31 I-316

doi: $10.5505 /$ tjtes.2016.40040

Copyright 2017

TJTES and ischemia time. ${ }^{[2-6]}$ There are generally accepted indications for replantation in the literature. In addition, the decision on replantation may also be influenced by improvements in microvascular techniques, patient preferences, technical capacity, and surgeon preferences. ${ }^{[7,8]}$

The aim of this study was to report the success rate of finger replantation surgery at our center and to discuss factors that can affect successful results and the replantation decision.

\section{MATERIALS AND METHODS}

A retrospective review of cases of digital replantation performed between January 2006 and December 2013 was conducted with the approval of the ethics committee of Ankara Training and Research Hospital. Traumatic total finger amputations were included in the study; subtotal amputations and any amputation proximal to the metacarpophalangeal joint were excluded. In our clinic, patient preference is accepted as a strong indication in the decision to perform replantation. With the exception of cases that can be considered to have 
an absolute contraindication for surgery, such as presence of severe systemic illness, amputations at multiple levels, and severe crush injuries, if surgery is only relatively contraindicated, according to the patient's desire, we favor surgery if we think that the finger is replantable.

The medical records of all the patients, including emergency department consultations, operative reports, and outpatient summaries, were reviewed. Demographic patient data of age, sex, hand dominance, and place of injury were also recorded. Mechanism (guillotine, crush, or avulsion), ${ }^{[8]}$ level of injury (according to the Tamai classification as described by Yoshimura $)^{[9]}$ of the involved digit, and length of hospitalization were also determined. Injuries were classified as severe if they fulfilled one of the following criteria stated by Vilkki and Göransson: amputation of the thumb through or proximal to the interphalangeal joint, or amputation of 2 or more fingers through the proximal interphalangeal joint.

Survival of the replanted digit, which was defined as digit viability for a minimum of $2 \mathrm{I}$ days, was used for the assessment of final outcome. ${ }^{[10]}$

Statistical analysis of groups was performed using SPSS for Windows, Version 15.0 (SPSS, Inc., Chicago, IL, USA) statistical software, with the level of significance set at $p<0.05$.

\section{RESULTS}

A total of 85 digit replantations were performed in 60 patients with complete medical records. Of those, 53 were male and 7 were female. The average age of the patients was 31 years, ranging from I to 72 years. Seven patients (12\%) were younger than 13 years of age. The left side was more often affected, with occurrence in 53 of the patients (62\%). The index finger was the most commonly replanted digit at $27 \%$ of the total, followed by the middle finger at $21 \%$, and ring finger and thumb replantations represented $20 \%$ and $19 \%$, respectively. The least commonly replanted digit was the little finger, with $13 \%$.

The mechanism of injury was crush in $56 \%$, guillotine (sharp) in $23 \%$, and avulsion in $21 \%$ of replanted digits (Fig. I). In all,

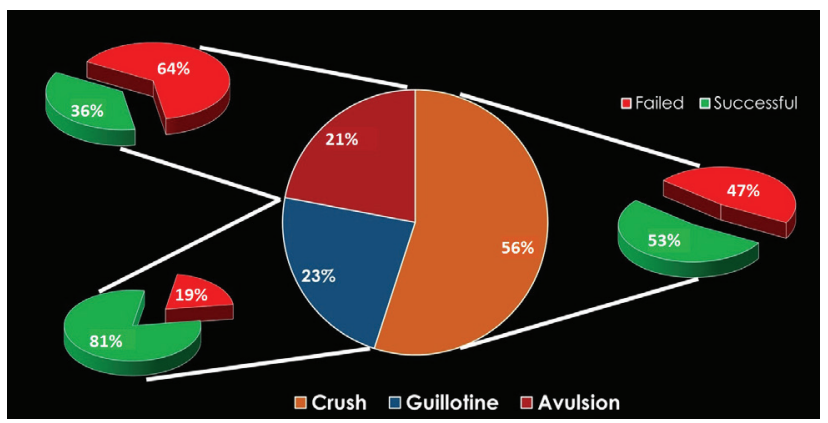

Figure 1. Percentage of replantations by mechanism and success rate for each mechanism.
$49 \%$ of the replantations were performed following amputation through or distal to Tamai level III (Fig. 2). Eleven patients underwent multiple-digit replantation and 49 underwent single-digit replantation. The thumb was replanted in 14 of the single-digit cases. A total of 18 patients (30\%) were classified as having severe injuries, according to the criteria stated by Vilkki and Göransson.

The lowest digit survival rate was found in patients older than 60 years of age, with a rate of $20 \%$. In patients younger than 13 years of age, the survival rate was found to be $31 \%$, whereas in the age group between 13 and 60 years, it was $55 \%(p>0.05)$ (Table I). Subgroups of the patients according to gender and where the injury occurred were also examined and revealed that $71 \%$ of the replantations were performed for work-related injuries. In the age group between 13 and 60 years of age, $88 \%$ of male amputations were due to workrelated injuries received at an industrial site, and $100 \%$ of female amputations were due to injuries that occurred at home $(p<0.05)$. Of work-related replantations, $77 \%$ were diagnosed as crush and avulsion injuries ( $p>0.05)$.

Nearly all of the patients were transferred to our hospital by an emergency medical care team, so we can say that transfer conditions were quite good. In the hospital, amputated parts were preserved in physiological saline solution-soaked sponges in sterile bags and stored in containers at $4^{\circ} \mathrm{C}$. Mean time from injury to surgery was 7 hours, ranging from 3 to 14 hours (Table I). Since the transfer of the patients was typically performed by a medical care team, we believe that the warm ischemia time was not very long. Although there are no clear data, it was estimated that warm ischemia time was not more than 30 minutes, followed by cold ischemia until surgery. In cases with ischemia time of more than 10 hours, digit survival rate decreased to $37 \%$, whereas when ischemia time was less than 6 hours, mean survival rate was 73\% (Table I) ( $>>0.05)$. It is not possible to provide precise data about the effect of transfer conditions on survival rate in this study, since transfer



Figure 2. Number of replantations by Tamai level. 
Table I. Associations between digit survival and variables

\begin{tabular}{|c|c|c|c|c|c|c|c|}
\hline \multirow[t]{2}{*}{ Variable } & \multicolumn{2}{|c|}{ Survived } & \multicolumn{2}{|c|}{ Failed } & \multicolumn{2}{|c|}{ Total } & \multirow[t]{2}{*}{$\mathbf{p}$} \\
\hline & $\mathbf{n}$ & $\%$ & n & $\%$ & n & $\%$ & \\
\hline Age (years) & & & & & & & 0.108 \\
\hline$<13$ & 4 & 31 & 9 & 69 & 13 & 15 & \\
\hline $13-60$ & 37 & 55 & 30 & 45 & 67 & 79 & \\
\hline$>60$ & 1 & 20 & 4 & 80 & 5 & 6 & \\
\hline Total & & & & & 85 & 100 & \\
\hline Sex & & & & & & & 0.008 \\
\hline Male & 41 & 55 & 34 & 45 & 75 & 88 & \\
\hline Female & 1 & 10 & 9 & 90 & 10 & 12 & \\
\hline Total & & & & & 85 & 100 & \\
\hline Hand laterality & & & & & & & 0.933 \\
\hline Left & 26 & 49 & 27 & 51 & 53 & 62 & \\
\hline Right & 16 & 50 & 16 & 50 & 32 & 38 & \\
\hline Total & & & & & 85 & 100 & \\
\hline Digit & & & & & & & 0.483 \\
\hline Thumb & 9 & 56 & 7 & 44 & 16 & 19 & \\
\hline Index & 8 & 35 & 15 & 65 & 23 & 27 & \\
\hline Middle & 10 & 56 & 8 & 44 & 18 & 21 & \\
\hline Ring & 8 & 47 & 9 & 53 & 17 & 20 & \\
\hline Little & 7 & 64 & 4 & 36 & 11 & 13 & \\
\hline Total & & & & & 85 & 100 & \\
\hline Tamai level & & & & & & & 0.614 \\
\hline I & 1 & 100 & 0 & 0 & 1 & I & \\
\hline II & 7 & 47 & 8 & 53 & 15 & 18 & \\
\hline III & 15 & 58 & II & 42 & 26 & 31 & \\
\hline IV & 10 & 40 & 15 & 60 & 25 & 29 & \\
\hline V & 9 & 50 & 9 & 50 & 18 & 21 & \\
\hline Total & & & & & 85 & 100 & \\
\hline Mechanism of injury & & & & & & & 0.036 \\
\hline Guillotine & 13 & 81 & 3 & 19 & 16 & 23 & \\
\hline Crush & 20 & 53 & 18 & 47 & 38 & 56 & \\
\hline Avulsion & 5 & 36 & 9 & 64 & 14 & 21 & \\
\hline Total & & & & & 68 & 100 & \\
\hline Time from injury to surgery (hours) & & & & & & & 0.287 \\
\hline$<6$ & 8 & 73 & 3 & 27 & II & 25 & \\
\hline $6-10$ & 15 & 63 & 9 & 37 & 24 & 56 & \\
\hline$>10$ & 3 & 37 & 5 & 63 & 8 & 19 & \\
\hline Total & & & & & 43 & 100 & \\
\hline
\end{tabular}

conditions were quite good. However, general medical knowledge tells us that conditions during transfer can have a direct affect on digit survival. Therefore, it is important that all members of medical transport teams and emergency units know how to preserve amputated parts properly. The mean length of hospitalization was 13 days, ranging from 2 to 32 days.
In total, 42 of the 85 digit replantations were successful, a success rate of $49.4 \%$. When grouped according to type of injury, success rates were $81 \%, 53 \%$, and $36 \%$ in guillotine, crush, and avulsion injuries, respectively (Fig. I). Chi-square analysis indicated that there was a significant difference in survival rate between groups $(p<0.05)$. 
Replantation was achieved in all patients in initial surgery; operation was concluded after confirmation of sufficient arterial and venous circulation, and no amputation and stump reconstruction was performed at that time. In the ultimately unsuccessful replantation group, 8 of 43 fingers were reoperated on. Patients were taken to the operating room in mean time of 10 hours (range: 6-14 hours) after recognition of symptom of arterial or venous insufficiency on mean of third day (range: $2-5$ days) following first operation. In the successful replantation group, 4 of 42 fingers were reoperated on after mean of 6 hours (range: 2-8 hours) after recognition of symptoms that can cause failure on mean of third day (range: 2-4 days).

Of the 4 cases of reoperation in the successful group, the problem was determined to be arterial in I finger and venous in the remaining 3 . The problem was arterial in 2 fingers and venous in 6 fingers for the reoperated 8 fingers in the failure group.

\section{DISCUSSION}

Despite microsurgical improvements, successful replantation still depends on many factors related to the patient, environment, and culture. There are well-defined indications for replantation, such as thumb amputation, single finger amputation distal to the insertion of the flexor digitorum superficialis tendon, multiple finger amputations, and amputation at any level in children. ${ }^{[5,8]}$ There are also absolute and relative contraindications for surgery. The surgeon's way of thinking can be important in the decision when considering relative contraindications. Although the indications in the literature are well known, we believe that strong patient desire is also a factor in the replantation decision. After the elimination of definite contraindications for surgery, once the patient's wishes are known, if we believe replantation is possible in cases that may be questionable, we recommend surgery. ${ }^{\left[{ }^{[I]}\right.}$

The success rate of replantations varies greatly in the literature. There are studies from Asian countries with $85 \%$ to $100 \%$ success rate. ${ }^{[6,9,12]}$ There are fewer reports about success rates from Western countries. In 2 studies from Canada and the United States, successful replantation was reported as $57 \%$ and $71 \% .^{[1,10]}$

In our study, success rate of replantation was similar to results reported in studies from Western countries. The disparity may be related to many factors. One is that the practice of clinical microsurgery was initiated by Tamai, and while it then spread quickly to the United States, Australia, and Europe, the technical experience of surgeons in Asian countries may be greater. ${ }^{[8,9]}$

Another reason for varied success rates in different reports may be related to factors regarding patient selection. For example, Waikakul et al. excluded patients with comorbid injuries and those with chronic illnesses, like diabetes mellitus, from their study. ${ }^{[6]}$ In that study, when a classification was performed according to injury type, the success rate was reported as $33.3 \%$ and $50.9 \%$ in crush and degloving injuries, respectively. ${ }^{[6]}$ In our study, the success rate was $81 \%$ in guillotine type injuries. The rate was $53 \%$ and $36 \%$ for crush and avulsion type injuries, respectively, and these percentages are quite similar to those seen in the literature. ${ }^{[6,9]}$

In addition, the age of the patient is also important and can affect the success of replantation. Although in our study, age was not significantly correlated with success rate, successful results were lower in children and the older age group than in adults $(31 \%, 20 \%$, and $55 \%$, respectively). Since the vessels are narrower and the venous vessel wall is thinner in children, the technical difficulties of replantation are greater in this age group, which affects the success rate. ${ }^{[13,14]}$ Also, broader indications for replantation in children and attempting replantation for almost all types of injury in this age group may also increase the number of unsuccessful cases. ${ }^{[15,16]}$ Greater loss of replantation in patients of older age may be correlated with weakness of the vascular structures.

One other patient-related factor that may affect results is the predisposition of the white race to thrombophilia when compared with the population of the Far East. ${ }^{[17]}$

In our study, the index and middle fingers were the fingers most often affected, as in previous studies. ${ }^{[13,18,19]}$

We found that gender significantly affected the success rate: unsuccessful replantations were seen in female patients more often than in male patients. A review of the literature reveals that various success rates have been reported related to gender. $^{[3,14]}$ Yu et al. stated in their meta-analysis of 2015 that gender did not significantly affect survival rate. ${ }^{[20]}$ Difference in survival between genders may be related to technical differences among centers and differences in case features. In addition, women have relatively narrower blood vessels than men, which may be a reason for a lower success rate in female patients in our study. The number of female patients was very small in the present study, and this also limits our ability to reach a conclusion about the effect of gender on success of the surgery.

Our results did not indicate that the amputation level according to the Tamai classification affected achieving a successful result. Nor did ischemia time significantly affect success rate. Although a statistically significant correlation was not found between ischemia time and success rate, the ratio of loss was $27 \%$ for cases with $<6$ hours of ischemia, while it increased to as much as $73 \%$ for cases with $>10$ hours of ischemia. In the literature, successful digit replantation has been reported after extended ischemia of up to 94 hours, but these reports are very few. ${ }^{[21,22]}$ Although it would seem that greater ischemia time would have a negative effect on 
replantation success and functional results, as in our study, a meta-analysis in the literature found that there was not a statistically significant difference between ischemia time $<12$ hours and $>12$ hours. ${ }^{[20]}$ This may be related to the fact that fingers have quite a bit less muscular tissue and can therefore tolerate longer period of ischemia. However, aside from the increased ischemic tolerance of the soft tissue of the fingers, it must be kept in mind that reperfusion damage can be very harmful at the cellular level, especially for the endothelial cells of the capillaries. This condition can lead to unsuccessful replantation and unsatisfactory functional results. ${ }^{[22]}$

In our study, the majority of the cases $(75 \%)$ were males in the age group of 13-60 years, and most of the injuries occurred at an industrial location. In contrast, all of the female patients were injured at home. This is likely due to the fact that males in this age group are mostly of working age and their work often involves greater physical labor and risk. There were more crush type injuries than any other type in our study, which was probably related to the large number of workplace injuries.

The mechanism of injury is also an important determinant in the achievement of a successful replantation. Although there is not a statistically significant difference between crush and avulsion type injuries, the failure rate after replantation attempt is significantly higher in these 2 groups compared with guillotine-type injuries. ${ }^{[20]}$ Choi et al. stated that a severe crush injury can be accepted as contraindication for digital replantation. ${ }^{[23]}$ Our results also revealed a significantly higher success rate in guillotine injuries compared with crush and avulsion injuries ( $81 \%, 53 \%$ and $36 \%$ respectively).

The reoperation decision and its timing are also important determinants for successful results after replantation. In our study, there was not a significant correlation between time elapsed before reoperation and success rate, but of the 12 reoperated patients, the 4 who were reoperated on sooner had successful results, which may suggest that earlier decision to reoperate can be finger-saving.

In conclusion, replantation is a difficult surgical procedure that requires meticulous work and an experienced team. It is clear that the success rate of replantation can be affected by many variables, from the transfer of the amputated finger to the quality of surgical equipment, and patient-related factors.

\section{Conclusion}

When different variables are kept in mind, our success rate after digital replantation was found to be similar to that in the literature. At this point, we believe that as the ability of surgeons to choose suitable patients for operation and the experience of surgeons grows, success rates will increase, too.

Conflict of interest: None declared.

\section{REFERENCES}

1. Neinstein RM, Dvali LT, Le S, Anastakis DJ. Complete digital amputations undergoing replantation surgery: a 10-year retrospective study. Hand (N Y) 2012;7:263-6. [CrossRef]

2. Beris AE, Lykissas MG, Korompilias AV, Mitsionis GI, Vekris MD, Kostas-Agnantis IP. Digit and hand replantation. Arch Orthop Trauma Surg 2010;130:1141-7. [CrossRef]

3. Dec W. A meta-analysis of success rates for digit replantation. Tech Hand Up Extrem Surg 2006;10:124-9. [CrossRef]

4. Janezic TF, Arnez ZM, Solinc M, Zaletel-Kragelj L. One hundred sixtyseven thumb replantations and revascularisations: early microvascular results. Microsurgery 1996;17:259-63. [CrossRef]

5. Soucacos PN. Indications and selection for digital amputation and replantation. J Hand Surg Br 2001;26:572-81. [CrossRef]

6. Waikakul S, Sakkarnkosol S, Vanadurongwan V, Un-nanuntana A. Results of 1018 digital replantations in 552 patients. Injury 2000;31:33-40.

7. McCabe SJ. Patient participation in the decision for replantation. Hand Clin 2001;17:351-5.

8. Morrison WA, McCombe D. Digital replantation. Hand Clin 2007;23:1-12. [CrossRef]

9. Yoshimura M. Indications and limits of digital replantation. JMAJ 2003;46:460-7.

10. Fufa D, Calfee R, Wall L, Zeng W, Goldfarb C. Digit replantation: experience of two U.S. academic level-I trauma centers. J Bone Joint Surg Am 2013;95:2127-34. [CrossRef]

11. Coban YK. Finger replantation without anticoagulant therapy. Edorium J Plast Cosmet Surg 2014;1:1-4.

12. Fukui A, Tamai S. Present status of replantation in Japan. Microsurgery 1994;15:842-7. [CrossRef]

13. Li J, Guo Z, Zhu Q, Lei W, Han Y, Li M, et al. Fingertip replantation: determinants of survival. Plast Reconstr Surg 2008;122:833-9. [CrossRef]

14. Hamilton RB, O'Brien BM, Morrison A, MacLeod AM. Survival factors in replantation and revascularization of the amputated thumb--10 years experience. Scand J Plast Reconstr Surg 1984;18:163-73. [CrossRef]

15. Kim JY, Brown RJ, Jones NF. Pediatric upper extremity replantation. Clin Plast Surg 2005;32:1-10. [CrossRef]

16. Michalko KB, Bentz ML. Digital replantation in children. Crit Care Med 2002;30(11 Suppl):S444-7. [CrossRef]

17. Dahlbäck B. Advances in understanding pathogenic mechanisms of thrombophilic disorders. Blood 2008;112:19-27. [CrossRef]

18. Largo TW, Rosenman KD. Michigan work-related amputations, 2008. J Occup Environ Med 2013;55:280-5. [CrossRef]

19. Kim WK, Lim JH, Han SK. Fingertip replantations: clinical evaluation of 135 digits. Plast Reconstr Surg 1996;98:470-6. [CrossRef]

20. Yu H, Wei L, Liang B, Hou S, Wang J, Yang Y. Nonsurgical factors of digital replantation and survival rate: A metaanalysis. Indian J Orthop 2015;49:265-71. [CrossRef]

21. Wei FC, Chang YL, Chen HC, Chuang CC. Three successful digital replantations in a patient after 84,86 , and 94 hours of cold ischemia time. Plast Reconstr Surg 1988;82:346-50. [CrossRef]

22. Lin CH, Aydyn N, Lin YT, Hsu CT, Lin CH, Yeh JT. Hand and finger replantation after protracted ischemia (more than 24 hours). Ann Plast Surg 2010;64:286-90. [CrossRef]

23. Choi MS, Lee JH, Ki SH, Ahn HC. Trends in digital replantation. Curr Orthop Pract 2012;23:284-8. [CrossRef] 
ORİJINAL ÇALIŞMA - ÖZET

\section{Parmak replantasyonları ile ilgili sekiz yıllık klinik deneyim:} Demografik özellikler ve sonuçlar

Dr. Melike Oruç, ${ }^{1}$ Dr. Koray Gürsoy, ${ }^{1}$ Dr. Kadri Özer, ${ }^{2}$ Dr. Özlem Çolak, ${ }^{3}$ Dr. Yüksel Kankaya, ${ }^{1}$ Dr. Nezih Sungur, ${ }^{1}$ Dr. Gürhan Mustafa Ulusoy, ${ }^{4}$ Dr. Uğur Koçer ${ }^{1}$

${ }^{1}$ Ankara Eğitim ve Araştırma Hastanesi, Plastik, Rekonstrüktif ve Estetik Cerrahi Kliniği, Ankara

${ }^{2}$ Aydın Devlet Hastanesi, Plastik, Rekonstrüktif ve Estetik Cerrahi Kliniği, Aydın

${ }^{3}$ Okmeydanı Eğitim ve Araştırma Hastanesi, Plastik, Rekonstrüktif ve Estetik Cerrahi Kliniği, İstanbul

${ }^{4}$ Özel Muayenehane, Ankara

AMAÇ: Mikrocerrahideki cerrahi ve teknik ilerlemelere rağmen halen parmak amputasyonlarının replantasyonu sonrasında tatminkar sonuçlar elde etmek zordur ve başarı oranlarını belirleyen birçok faktör mevcuttur. Bu yazıda, replantasyonun başarısını değiştirebilecek faktörleri tartışmak amaçlandı.

GEREÇ VE YÖNTEM: Altmış hastada uygulanan 85 parmak replantasyonunun geriye dönük analizi yapıldı. Revaskülarizasyonlar ve metakarpofalangeal eklemin proksimalindeki replantasyonlar çalışma dışı bırakıldı. Hastaların demografik özellikleri, yaralanma yeri, yaralanma mekanizması, amputasyon seviyesi ve başarı oranları değerlendirildi.

BULGULAR: Ortalama yaşları 3 I olan 53 erkek ve yedi kadın hasta çalışmaya dahil edildi. İşaret parmağı en sık replante edilen parmaktı (\%27). Sol el en sık etkilenen taraftı (\%62). Yaralanma mekanizması, replante edilen parmakların \%56'sında ezilme, \%23'ünde giyotin tip, \%2 I'inde ise avülziyondu. Başarı oranları giyotin, ezilme ve avülziyon tipi yaralanmalarda sırasıyla \%8I, \%53 ve \%36 olarak bulundu.

TARTIŞMA: Sonuç olarak, replantasyonların başarı oranlarını belirlemede yaralanma tipi ve kişisel değişkenler oldukça önemlidir. Replantasyon cerrahisinin sonuçlarına etki edebilecek değişkenler hakkında bilgi sahibi olmak, hasta ve yakınlarını doğru bilgilendirme konusunda el cerrahlarının yanında acil cerrahi hizmeti veren hekimler için de oldukça yönlendirici olacaktır.

Anahtar sözcükler: Amputasyon; mikrocerrahi; parmak; replantasyon.

Ulus Travma Acil Cerrahi Derg 2017;23(4):31 I-316 doi: 10.5505/tjtes.2016.40040 